\title{
The role of oat products in the prevention and therapy of type 2 diabetes, hypercholesterolemia and obesity*
}

\author{
Rola przetworów owsianych w profilaktyce i terapii cukrzycy typu 2, hipercholesterolemii oraz \\ otyłości
}

\author{
Katarzyna Janda, Anna Orłowska, Katarzyna Watychowicz, Karolina Jakubczyk ${ }^{\bowtie}$ \\ Pomorski Uniwersytet Medyczny w Szczecinie, Katedra i Zakład Żywienia Człowieka i Metabolomiki, ul. Broniewskiego 24, 71-460 Szczecin \\ Pomeranian Medical University in Szczecin, Department of Human Nutrition and Metabolomics \\ ه jakubczyk.kar@gmail.com
}

\begin{abstract}
A healthy diet, of which unrefined grain products are an essential element, is crucial to maintaining health and well-being. Both oats and oat products have been used for centuries and are a widely popular dietary component. They are rich in nutrients, vitamins and minerals, as well as other biologically active compounds, which gives them many health-promoting properties. Because of their high nutritional value, these products are widely used in many branches of industry.

The aim of this article is to present the current body of knowledge about the influence of oat products on human health, and also their industrial applications. A special emphasis is placed on the relationship between the intake of products made from oats and the development and treatment of such disorders as
\end{abstract}

type 2 diabetes, cardiovascular diseases and excess body weight. There are many scientific reports indicating that the incorporation of oat products into the diet is associated with beneficial effects in the context of the above conditions, notably due to the high content of water-soluble dietary fibre, particularly $\beta$-glucans, which deserve special recognition. According to the body of academic literature, high consumption of the latter is linked to enhanced glycemic control, reduction in blood cholesterol and may also contribute to weight loss in overweight and obesity. For these reasons, oat products deserve special attention and should be recommended for both prophylactic and therapeutic use in metabolic disorders.

Keywords: Avena; metabolic disorders; beta-glucans.

\begin{abstract}
ABSTRAKT
Właściwa dieta, której elementem są niskoprzetworzone produkty zbożowe, jest czynnikiem koniecznym do zachowania zdrowia. Zarówno owies, jak i przetwory owsiane są stosowane od wieków i cieszą się dużą popularnością jako składnik diety. Są one bogate w składniki odżywcze, witaminy i minerały oraz inne związki o charakterze biologicznie czynnym, dzięki czemu wykazują wiele właściwości prozdrowotnych. W związku z wysoką wartością odży wczą produkty te znalazły szerokie zastosowanie w wielu gałęziach przemysłu.

Celem pracy było przedstawienie aktualnego stanu wiedzy dotyczącej wpływu produktów owsianych na zdrowie człowieka, a także ich wykorzystania w przemyśle. Szczególną uwagę poświęcono zależności pomiędzy spożyciem produktów uzyskanych z ziarna owsa a wystąpieniem i leczeniem takich
\end{abstract}

zaburzeń, jak cukrzyca typu 2, choroby układu krążenia czy nadmierna masa ciała. Istnieje wiele doniesień naukowych świadczących, że włączenie do diety przetworów owsianych wiąże się z korzystnym działaniem w kontekście wymienionych schorzeń, a na szczególne zainteresowanie zasługuje wysoka zawartość frakcji rozpuszczalnej włókna pokarmowego, a zwłaszcza $\beta$-glukanów. Jak można wnioskować z literatury fachowej, ich wysokie spożycie wiąże się z lepszą kontrolą glikemii, obniżeniem stężenia cholesterolu we krwi, a także może przyczyniać się do obniżenia masy ciała u osób z nadwagą czy otyłością. Z tych względów produkty owsiane zasługują na szczególną uwagę i powinny być zalecane zarówno w celach profilaktycznych, jak i leczniczych w przypadku chorób o podłożu metabolicznym. Słowa kluczowe: Avena; choroby metaboliczne; beta-glukany.

\section{INTRODUCTION}

Oat grain is a valuable source of various biologically active compounds. These compounds can be used in many industrial sectors, as well as for the purposes of prevention and treatment of health conditions. Oats and oat products have been used for centuries and are an incredibly popular dietary component, a remedy for various health ailments, and a source of valuable components in many branches of industry. The growing

interest in healthy lifestyles and in the properties of widely available natural materials has earned recognition for oats and oat products in the eyes of those following the rules of healthy nutrition, and those interested in preventing diseases and supporting therapies. It is common knowledge that a wellbalanced diet is essential to maintaining good health, while an imbalanced diet may be a contributing factor in the development of metabolic disorders and so-called lifestyle diseases.

* The project was financed under the program of the Minister of Science and Higher Education under the name "REGIONALNA INICJATYWA DOSKONAŁOŚCI" in 2019-2020. Project No. 002/RID/2018/19 financing amount PLN 12,000,000. 
The aim of this paper is to address the various potential applications of oats and oat products and to present its positive impact on the human body.

\section{CHARACTERISTICS OF OAT PRODUCTS}

The oat (Avena) belongs to the grass family, encompassing some 35 species originating from north Africa, central Asia and the Mediterranean region, some of them grown as a grain crop, some naturalised and some regarded as weeds. One species, the common oat (Avena sativa), is seen as the most important, as it is widely cultivated in regions with a temperate and cool climate. The common oat grain is used as a raw material in the production of livestock feed and also in the production of oatmeal and oat flakes with a wide range of cooking applications [1]. The oat, as a plant rich in various biologically active compounds, may be used in the prevention and treatment of many health conditions. Oat grain is used in human nutrition, and that is why from the nutritional point of view it is crucial to establish the health-promoting benefits of that particular element of plant morphology [2].

The most popular oat products include oat flakes, which can vary in terms of degree of granulation and toasting, oat bran, as well as products obtained directly from fragmented (steel-cut, ground), dehusked oat grain, better known as oat groats. Oat products (flakes, bran, meal or $\beta$-glucan preparations) are often added or used as a base in bread, in granola or muesli-type mixes of cereals, concentrated foods (including instant foods, cocoa) and confectionery products. The content of oat flakes in bakery products may amount up to $50 \%$, and oatmeal or bran to $20-30 \%$. Oat bran is currently one of the most popular oat products. It may be obtained from oat grain or oat flakes which are fragmented, sized and separated multiple times, to remove the starchy endosperm from the fibrerich fractions. It should contain no less than $18-25 \%$ (16 g/100 g dry weight, d.w.) of dietary fibre and 5.8-8.9\% (5.5 g/100 g d.w.) $\beta$-glucans. Oat bran is high in proteins and contains considerable amounts of vitamin E and B-group vitamins; it has a higher fat content than oat flakes, but a lower level of minerals. There are many new oat products launched in the global market with an enhanced $\beta$-glucan content. They include: fruit beverages fortified with oat $\beta$-glucans (no less than $5 \%$ content), oat milk, and fermented beverages based on wholegrain oatmeal with the addition of Lactobacillus plantarum. Oat milk is made from oatmeal or fine oat flakes which are exposed to $\beta$-amylase and hydrothermal processing to increase the levels of maltose and dextrins, producing a drink with a similar sweetness level as milk. One should bear in mind, however, that processed oat products, such as bars, biscuits and instant foods, may contain more than $10 \mathrm{~g}$ of saccharose per portion and in excess of 200 kcal. Other products made from oats are glucan preparations sold under the trade names: C-Trim, Nutrim, Oatrim. The latter is a polysaccharide preparation obtained from oat bran or meal through the enzymatic degradation of starch. It is characterised by a high content of water-soluble dietary fibre $(5-10 \%$ $\beta$-glucans) and is used as a fat substitute with a reduced calorie content (1 kcal/g) in the processing of various foods, such as cheese, chocolate, margarine, butter, confectionery and baked goods. Likewise, C-Trim and Nutrim, rich in $\beta$-glucans (5-50\%), may be used as fat substitutes and/or functional additives in food production. The US market also contains oatmeal marketed under the trade name Avenex, which is used as a stabiliser and antioxidant to extend the shelf life of such products as: fish oils, dried egg products, milk and milk products, as well as meat and fish products. In Poland, the following products are made from oat grain: oat bran, flakes, meal, groats, middlings, fibre preparations (with $\beta$-glucan content at 30\%) and mixes of cereals and fruits such as muesli and granola $[3,4]$.

\section{NUTRITIONAL VALUE OF OAT PRODUCTS}

Oat grain contains a wide range of valuable ingredients which determine its usability in processing and in human nutrition. Oats are an excellent source of protein rich in exogenous amino acids, with a different fractional composition than other cereals and a high nutritional value. Globulins account for approx. $50-80 \%$ of the protein complex in oat grains, with the content of glutelins and prolamins estimated at $20-25 \%$. Such a ratio is indicative of the high biological value of proteins among cereals, found only in oats. The quality of the proteins, reflecting their biological value, depends on the sum of the content of individual exogenous amino acids, as well as on the mutual proportions between them. By eating $100 \mathrm{~g}$ of oat flakes, one may cover the daily requirement for 7 out of 10 exogenous amino acids.

The domestic cultivars of oats have a much higher fat content than other cereals (barley, wheat, rye and corn). The fat content is in the range of $4-10 \%$ per $100 \mathrm{~g}$ of the product. Oat fat is a source of unsaturated fatty acids, accounting for approx. $80 \%$ of all acids. They include: linoleic acid (24-48\%), oleic acid (29-53\%), $\alpha$-linolenic acid (1-5\%), as well as some long chain fatty acids: arachidonic, docosahexenoic and eicosapentenoic acid. In raw oat fat, the content of essential fatty acids (EFA) amounts to approx. 40\%, which corresponds to $2.5-3.0 \%$ content in oat flakes. Eating $100 \mathrm{~g}$ of oat flakes is enough to cover approx. $30 \%$ of the daily requirement for linoleic acid. Oat oil is very well tolerated by the human body. A diet rich in oat products is also observed to have a hypocholesterolemic effect, probably owing to the interaction of the nutrients contained in oats: linoleic acid, polyphenols, phytosterols and dietary fibre. Compared to other cereals, oats have the lowest content of polysaccharides. The total content of oligo- and monosaccharides amounts to approx. $1 \%$, made up primarily of glucose and fructose (52 and $91 \mathrm{mg} / 100 \mathrm{~g}$ ), raffinose (190 mg/100 g) and sucrose (640 mg/100 g). Starch is the predominant polysaccharide, accounting for approx. 55\% of the grain, which is still about $10 \%$ less than in other cereals. Starch is without a doubt a major storage substance of cereals, accumulated in the endosperm - the germ and bran do not contain it. Other important substances are complex polysaccharides, such as cellulose and hemicellulose, which are the structural components 
of the cell wall and constitute the insoluble fraction of dietary fibre. Oat grain and oat products are an important source of dietary fibre in the daily diet. Whole oat grains prior to hulling have an average fibre content of $32 \%$, while in oat flakes fibre averages $14 \%$, with close to $8 \%$ in the soluble fibre fraction and $6 \%$ of the insoluble fraction. Oats are the only cereal with such a high level of soluble fibre fraction, which plays the more important role in the context of human nutrition. The most essential component of soluble fibre found in oats are $\beta$-glucans. They are a mixture of linear unbranched chains of $\beta$-D-glucose, linked by $\beta-1,6, \beta-1,4, \beta-1,3$ and $\alpha-1,4$ glycosidic bonds. The content of dietary fibre in cereal products differs because of the non-uniform distribution of fibre in the grain. Wholegrain bread, flour, flakes and groats provide the most valuable sources of $\beta$-glucans. Oat fibre is particularly interesting, due to its numerous health-promoting properties, such as improving glycemic control or hypocholesterolemic action. By activating the phagocytes responsible for absorbing cell debris and unwanted substances, $\beta$-glucans help reinforce the body's immune system, which makes them potentially useful in cancer therapies. What is more, by stimulating the development of healthy bacterial flora in the large intestine, which feeds on dietary fibre, they contribute to enhancing resistance to infections. Fats originating from oat grains were found to contain compounds with strong antioxidant properties. Among them are polyphenols, including hydroxycinnamic acids (caffeic and ferulic) and hydroxybenzoic acids. They act as reducing agents for hydroxides and peroxides, and also inhibit free radical reactions. In addition, they exhibit a bacteriostatic action and have a beneficial influence on the heart and the circulatory system, as well as prevent neoplastic diseases and chronic inflammatory conditions. Other wellknown antioxidants found in oat grains include phenolic acid esters and amides, vitamin E, alkylphenols, avenanthramides and flavonoids. These compounds bind to metals, particularly copper and iron, blocking enzymatic oxidation processes.

Oat products are a rich source of mineral salts. The ash content in whole grain oats is estimated in the range of 2.7$3.7 \%$, and mineral compounds are concentrated in the outer layer of the kernel. Hulled grain contains approx. $50 \%$ of the mineral content of the whole grain. The mineral content of oat grains is positively correlated with the level of soluble dietary fibre fraction. Notable minerals include compound forms of magnesium, calcium, iron, phosphorus and considerable amounts of silicon. Moreover, whole oat grains, green oat, oat flakes and bran contain large amounts of zinc. The low sodium content makes oat products suitable for people with cardiovascular disorders. Oat grains are regarded as a good source of vitamin E, thiamine (vitamin B1) and pantothenic acid $-100 \mathrm{~g}$ of oat flakes can satisfy $40 \%$ of the daily requirement for vitamin B1 and approx. 20\% for vitamin E. An isoform of vitamin E, $\alpha$-tocotrienol, inhibits cholesterol synthesis in the liver, bringing down low-density lipoprotein (LDL) cholesterol and total cholesterol levels in blood. An adequate intake of vitamin $\mathrm{E}$ helps reduce the risk of developing prostate cancer (by approx. 43\%), breast cancer, oral, gastric and throat cancers, and body vitamin E levels are observed to be inversely proportional to cardiovascular disorders, including atherosclerosis [5].

\section{INDUSTRIAL APPLICATIONS OF OAT PRODUCTS}

Contemporary agriculture uses both husked and naked cultivars of oats, with different chemical composition. The naked grain, with a lower content of dietary fibre than its husked counterpart, but with higher levels of fats and proteins, offers new opportunities for applications of oats in food processing and animal nutrition. There are 2 trends in oat cultivation worldwide - to improve grain quality by growing special cultivars rich in bioactive compounds, and to increase yields. The highest-yielding commercial cultivar of oats is Bingo, producing grain of high consumer value and bioactive content. To use oats as a material in different industries, the requirements of the target markets must be taken into consideration. The pharmaceutical and food industries value varieties with a high content of $\beta$-glucans, specific lipids and antioxidants. On the other hand, livestock feed manufacturers opt for oat varieties with a low level of $\beta$-glucans, but rich in proteins and lipids. Manufacturers of groats and oatmeal choose cultivars with large kernels and a low content of the lemma and lipids, to optimise processing yields. The introduction of new husked and naked oat cultivars significantly enhances the range of potential applications of the plant in the food industry. New methods and technologies of oat fractionation have made it possible to develop strategies for the application of oats as a material in various industrial sectors. Oat products, as well as oat grains, are employed in new-generation products in pharmaceuticals, cosmetics, chemicals, foods, as well as for medicinal and dietary purposes:

- pharmaceutical industry: tocopherols, green oat extracts, oat grass preparations, $\beta$-glucans: ingredients of medications; toasted oats: a cigarette additive reducing nicotine levels;

- cosmetic industry: $\beta$-glucans (hydrocolloids) with powerful moisturising properties: ingredients of shower gels and hydrogels for wound dressing, cleansing milk; hydrolysed oat protein: ingredient of cleansing milk, shampoos, hair conditioners, creams for atopic dermatitis, lipsticks; oat starch: powdered donning lubricant for rubber gloves; oat fat (linoleic acid): an ingredient of toilet soaps;

- food industry: $\beta$-glucans: alternative thickeners and stabilisers; oatmeal: stabiliser and antioxidant; modified oat proteins with improved solubility, emulsifying, foaming, and fat binding properties: additives in functional food production;

- chemical industry: oat hulls: adhesive filler in the production of plywood; oat starch: adhesive component; oat proteins: active substance agents and carriers in plant protection products;

- paper industry: fibre binder for a smooth finish;

- herbalism: aqueous extracts of non-lignified parts of the plant (silica): expectorant, analgesic properties, beneficial for skin, hair, bones and nails; 
- catering: processed oat grains: alternative for groats or rice in dinner and breakfast dishes; oat bran: breadcrumbs substitute for coating foods;

- other: oat hulls: used in the production of cat litter; material used for energy purposes [4].

Oats, providing a relatively cheap material, are still underestimated in Poland. Oat grain and oat products have a wide range of applications in the economy, and also - with their exceptional physiological and nutritional benefits - in the daily diet, offering the potential to improve the health of the general population, and playing a positive role in the prevention and treatment of health conditions.

\section{THE ROLE OF OAT PRODUCTS IN THE PREVENTION AND TREATMENT OF TYPE 2 DIABETES}

Type 2 diabetes is a metabolic disorder. It is believed to arise when tissues develop a resistance to insulin, a hormone secreted by the pancreas [6]. According to data from 2017, in high income countries, type 2 diabetes accounts for up to $87-91 \%$ of all diabetes cases [7]. The typical type 2 diabetes patient presents an excessive production and secretion of insulin, while insulin resistance in tissues leads to hyperglycemia [6]. The most common causes of type 2 diabetes include such lifestyle factors as: excessive consumption of (mainly highly processed) food, low physical activity and obesity (particularly the abdominal type). Early management of type 2 diabetes is vitally important because, with the progression of the condition, patients face the risk of serious complications such as: diabetic nephropathy, retinopathy and neuropathy (including diabetic foot problems), ischemic heart disease and atherosclerosis [8].

The primary objective in the dietary management of diabetes is to achieve and maintain near-normal blood glucose concentrations (glycemia). Carbohydrates are the key macronutrient which can determine whether or not this objective is accomplished [9]. Among carbohydrate-rich foods, the following are most recommended in diabetes: wholegrain cereal products, fresh vegetables, fruit, and dairy with a low fat content. Patients should concentrate on food products with a low glycemic index and a high level of dietary fibre, as such products improve glycemic control in diabetes [8]. Oat products may be included in this category. The addition of oatmeal or oat extrudates to soups, confectionery products and breads reduces the post-meal (postprandial) glycemic response [2].

In the past few years there have been numerous reports based on clinical trials which have investigated the influence of a high-fibre diet on the prevalence of type 2 diabetes. A relationship was observed between the use of products containing dietary fibre and reductions in the risk of diabetes [10]. The experiments carried out within the framework of the European Prospective Investigation into Cancer and Nutrition (EPIC) in 2003 demonstrated that the risk of developing type 2 diabetes is inversely proportional to the consumption of fibre, particularly those contained in cereals (including oats) and vegetables [11]. Research findings indicate clearly that increasing the amount of dietary fibre in the diet (especially from oats) significantly reduces fluctuations in blood sugar levels, and lowers the postprandial glycemic response [12]. Oat products, particularly those used most commonly like oat flakes, oatmeal and oat bran, have a relatively lower glycemic index than the same products obtained from wheat, barley or corn. The level of $\beta$-glucans in the given product significantly impacts on the control of blood glucose levels after it is consumed. The glycemic index of a product can be reduced by an average of $1 \%$ by incorporating $1 \mathrm{~g}$ of oat $\beta$-glucans in the meal. It is important to note that oat flakes with an average thickness of $1 \mathrm{~mm}$, without pre-processing, are associated with a lower glucose and insulin response than oat flakes with an average thickness of $0.5 \mathrm{~mm}[3]$. The documented ability of $\beta$-glucans to bring down post-meal serum glucose levels, as well as their beneficial effects on insulin sensitivity, mean that incorporating oat products into the daily diet may contribute to reducing the prevalence of type 2 diabetes in the human population. The observed hypoglycemic effects may be explained by the ability of $\beta$-glucans to bind water and form a gel inside the digestive tract, which increases the viscosity of the food, delays gastric emptying and increases gastrointestinal transit time. The compounds also affect the secretion of gastrointestinal hormones. The consumption of $\beta$-glucans is associated with a delayed absorption of nutrients, caused by impeding the accessibility of food to digestive enzymes responsible for breaking down the individual nutrients (including carbohydrates). In one study, breakfast cereal with the addition of $5 \mathrm{~g}$ of oat $\beta$-glucans eaten by subjects with type 2 diabetes, caused a decline in postprandial glycemia by an average of $50 \%$ and insulin response by approx. $35 \%$, in comparison to the values observed after the consumption of a standard breakfast containing $35 \mathrm{~g}$ of carbohydrates. It is important to note, however, that even a $3.8 \mathrm{~g}$ dose of $\beta$-glucans was associated with a statistically significant reduction in postprandial insulin levels. Interestingly, in order for the hypoglycemic action of oat $\beta$-glucans to be possible, the given foodstuff must contain at least $4 \mathrm{~g}$ of $\beta$-glucans per $30 \mathrm{~g}$ of available carbohydrates in a portion. In the study, the subjects who consumed a minimum of $5 \mathrm{~g}$ of oat $\beta$-glucans reported an extended postprandial satiety, which in turn led to a reduced calorie intake in subsequent meals [13]

\section{THE INFLUENCE AND MECHANISM OF ACTION OF OAT PRODUCTS ON IMPROVING THE LIPID PROFILE}

Cholesterol is a compound belonging to the steroid family, probably best known for its involvement in cardiovascular diseases and atherosclerosis. It plays important biochemical roles as a precursor of steroids, such as e.g. sex hormones and vitamin D [14]. Despite the beneficial functions of cholesterol in the human body, elevated levels are associated with adverse health effects. Hypercholesterolemia is the most crucial risk factor in 
the development of atherosclerosis and other pathologies in the cardiovascular system. Cardiovascular diseases are currently the most common cause of death worldwide, including Poland. Atherosclerosis is regarded as a critical factor in their development. The factors responsible for the development of cardiovascular system diseases include, among others, an unbalanced diet, arterial hypertension, excess body weight, tobacco smoking, excessive consumption of alcohol and a low level of physical activity.

The best-known method for managing disorders of lipid metabolism, including hypercholesterolemia, is the use of medication. It is assumed, however, that any therapeutic approach must be founded on non-pharmacological interventions, including physical activity and a healthy diet [15]. The diet should be well balanced, with a prominent role reserved for carbohydrates, which should be eaten in the form of wholegrain cereal products and pulses. In studies carried out on human and animal models, a diet with a high content of $\beta$-glucans from oats was observed to reduce plasma cholesterol levels, the main risk factor for atherosclerosis. The reduction of cholesterol levels by the compound is brought about by changes taking place in the upper part of the gastrointestinal tract. They are related to the fact that water-soluble dietary fibre factions form gel-like network structures, which delay the absorption of nutrients in the intestine, alter the viscosity of the fecal mass and extend subjective satiety [16].

Beta-glucans, which are polysaccharides belonging to the water-soluble dietary fibre fraction, are capable of forming gel matrices in the lumen of the small intestine. The associated significant increase in the binding and excretion of cholesterol, bile acids and their metabolites in the feces, redirects the pathway of cholesterol production in the liver to the hepatic synthesis of bile acids. A human diet enriched with $30 \mathrm{~g}$ of oat grain fibre increased the release of bile acids into the lumen of the small intestine by more than $50 \%$ compared to the diet without. Patients with ileostomy who received $11.6 \mathrm{~g}$ of $\beta$-glucans daily were observed to secrete $40 \%$ more bile acids and cholesterol, as well as exhibiting a significantly higher activity of cholesterol 7- $\alpha$-hydroxylase, which plays an important role in the biosynthesis of bile acids, compared to the subjects eating a diet without added $\beta$-glucans. A diet rich in $\beta$-glucans resulted in a decline in the amount of cholesterol available for lipoprotein synthesis, and also a higher number of LDL receptors in the liver, which may explain the reduction of plasma LDL cholesterol levels.

Another mechanism explaining the hypocholesterolemic effect of $\beta$-glucans, is associated with the formation of shortchain fatty acids (SCFA) in the large intestine in the course of fermentation of the soluble fibre fraction. Propionic, butyric and acetic acid, the products of fibre fermentation, are osmotically active and, in addition, are capable of modifying lipid and carbohydrate metabolism in the liver. A daily dose of $6 \mathrm{~g}$ of oat $\beta$-glucans administered for 6 weeks to subjects with hypercholesterolemia, caused a marked reduction of LDL cholesterol and total cholesterol levels compared to the baseline. A meal containing oat products with a high level of $\beta$-glucans may affect postprandial lipoprotein metabolism. Products rich in water-soluble dietary fibre slow down the time it takes for food to pass through the stomach, while also extending the gastrointestinal transit time, inhibiting lipid absorption in the small intestine, and modifying pancreatic enzyme activities. They additionally downregulate intestinal lipoprotein production and triglyceride resynthesis, which may ultimately lead to alterations in the composition or proportions of intestinal fractions of very low density lipoprotein (VLDL) and chylomicrons [13].

\section{THE ROLE OF OAT PRODUCTS IN THE PREVENTION AND THERAPY OF OBESITY}

Obesity is unquestionably a major health problem, becoming a real epidemic of the 21st century. Over the past 30 years, a significant upswing in the prevalence of overweight and obesity has been observed in the majority of countries around the world. It is estimated that the number of obese children up to the age of 18 has tripled in the last decade of the last century. Worldwide, the problem of overweight affects approx. 155 million children of school-going age, with 30-45 million among them being obese; additionally, there are 22 million overweight children under the age of 5 [17]. In Polish society, obesity affects approx. $22 \%$ of men with more than $45 \%$ of men overweight, while among women the respective figures are $29 \%$ and $35 \%$. With such a share of the population carrying excess body weight, Poland occupies one of the highest positions in Europe [18].

Obesity is a condition characterised by weight gain from an excessive accumulation of adipose tissue in the body. In its pathogenesis, key roles are played by: environmental factors (mainly physical activity and diet), genetic factors, cultural and social factors and hormonal status [19]. Excessive accumulation of adipose cells, especially in the abdomen, is associated with an elevated risk of cardiovascular complications, as well as that of the metabolic syndrome and certain cancers. Obesity in children may adversely affect the development of bones and joints, leading to the development of flat feet, bad posture, varus/valgus knee deformities. In boys, it may be responsible for gynecomastia and disorders of pubertal development, and in girls it sometimes causes menstrual disorders [18].

The steadily rising prevalence of obesity is primarily caused by the contemporary diet - high in calories and fat, poor in minerals, with insufficient amounts of fruits and vegetables, and consequently low dietary fibre. Physical exercise accounts for as little as $20 \%$ of the effort to maintain normal body weight [ 17 , 18]. The preferable approach is to follow a low-energy diet which should include wholegrain cereal products on a daily basis [20]. Oats and oat products provide an important source of dietary fibre in human nutrition. The whole oat grains prior to hulling have an average fibre content of $32 \%$, and oat flakes contain approx. $14 \%$, with more than $6 \%$ of the insoluble fraction and close to $8 \%$ of the soluble fibre fraction, which includes $\beta$-glucans. Meals rich in dietary fibre typically have a larger amount per 
portion and lower energy density, which means that a satisfying portion provides a lower calorie content compared to meals low in dietary fibre. With a larger volume of food, the sense of fullness (satiety) is achieved sooner and, as a result, the person consumes fewer calories without feeling food-deprived. For this reason, oat products may be beneficial in reducing excess body weight [5]. The constituents of the soluble fibre fraction have a water-binding capacity. This capacity extends the time it takes for food to pass through the stomach, which has beneficial effects on the efficiency of the digestion, absorption and enhanced subjective satiety after meals [10]. Beta-glucans also have properties preventing the development of metabolic syndrome because they bring down the glycemic index and modulate the levels of ghrelin and leptin, the hormones responsible for regulating the sensations of hunger and satiety. The low glycemic index of oat products (on average 40) produces greater satiating effects than those of products with a high glycemic index, which is due to the presence of indigestible forms of carbohydrates included in oat products [21].

Rebello et al. [22] also observed positive effects of oat flakes on enhanced satiety, suppression of appetite and reduced frequency and desire to snack after a meal. The authors attributed these beneficial effects in particular to $\beta$-glucans and their properties imparting viscosity to food. The extended contact between food and the epithelium of the small intestine activates protein hormones responsible for appetite control at the neural and hormonal level. To maintain the highest possible viscosity of $\beta$-glucans, the processing of oat flakes should be limited to the minimum. In the experiment referred to above, subjects ate $350 \mathrm{~g}$ of oat flakes in 3 forms (with a different degree of granulation) and observed the satiety, appetite and desire to eat immediately after the meal and $4 \mathrm{~h}$ later. The results were inversely proportional to the degree of processing - the least durable appetite suppression was provided by instant oat flakes. Based on these findings, it may be concluded that the effectiveness of weight loss efforts may be significantly affected by the degree of oat product processing [22]. In turn, a study carried out by researchers from Taiwan [23] demonstrated the effects of oat products on the visceral distribution of adipose tissue and on obesity prevention. The study included individuals aged between 18-65 with a diagnosis of overweight or obesity. After 12 weeks, during which the study group followed a diet containing oat cereal rich in $\beta$-glucans, the findings pointed to a positive influence of the consumption of oat products on weight loss, as well as reduced body fat and waist-to-hip ratio in the study participants. Reduced hepatic lipid accumulation and enhanced insulin sensitivity were observed in participants with visceral adiposity. The study confirms the beneficial effects of oat products on weight loss, the impact on reducing visceral fat, improving the lipid profile and liver function [23]. On the basis of the cited papers, it may be concluded that products rich in dietary fibre, both water-soluble and insoluble, and with a low glycemic index, exert the greatest satiating effects by stimulating satiety-generating mechanisms.

\section{CONCLUSIONS}

Oats and oat products are without a doubt an excellent source of valuable compounds which may be successfully used in different industrial sectors, and also in the prevention and treatment of many health conditions. Oat grains as a raw material have industrial properties lending themselves to applications in cosmetics, pharmaceuticals, food, papermaking, energy, herbalism, catering and many other economic sectors. In light of the steadily growing prevalence of conditions referred to jointly as lifestyle diseases, such as type 2 diabetes, hypercholesterolemia and obesity, experts are looking for methods to support preventive and therapeutic interventions in these conditions. With the high content of dietary fibre and its water-soluble fraction - notably $\beta$-glucans - in oat grain and oat products, this material appears to be the long-sought remedy to counteract the spread of lifestyle diseases. The treatment of type 2 diabetes, a chronic disorder of carbohydrate metabolism resulting from an unbalanced, low-fibre and high-energy diet, and a neglect of regular physical activity, may be successfully supported by incorporating oat products into the daily diet. The presence of oat $\beta$-glucans, which form a gel in the gastrointestinal tract, provides a markedly improved control of postprandial glycemia. Moreover, with the high content of water-insoluble dietary fibre fraction, the meals have a low glycemic index, which helps prevent peaks in insulin levels after eating. A diet rich in dietary fibre, which can be found in oat products, is particularly recommended to people with high serum cholesterol levels. This is due to the presence of $\beta$-glucans which create gel matrices in the small intestine and effectively bind bile acids and cholesterol, thus downregulating endogenous cholesterol synthesis in the liver, simultaneously reducing total cholesterol levels in the body. The growing problem of overweight and obesity calls for strong measures aimed at reducing the number of people with excess body weight. A fibre-rich diet can considerably contribute to lasting weight loss. Oat products incorporated into the daily diet of obese patients provide for long-term postprandial satiety, reducing the desire for snacking, while consequently bringing down the calorie intake and facilitating weight loss. In summary, considering such a wide range of applications, it may be concluded that both oats and oat products are a valuable material both for industrial applications and in the prevention and treatment of many diseases.

\section{REFERENCES}

1. Pieszczachowicz J, Dąbrowski M, Doboszewska A, Doboszewski R. Popularna encyklopedia powszechna. Kraków: Oficyna Wydawnicza; 2002.

2. Bartnikowska E. Przetwory z ziarna owsa jako źródło ważnych substancji prozdrowotnych w żywieniu człowieka. Biul Inst Hod Rośl 2003;229:235-45.

3. Lange E. Produkty owsiane jako żywność funkcjonalna. Żywn Nauka Technol Jakość 2010;3(70):7-24.

4. Kawka A, Achremowicz B. Owies - roślina XXI wieku. Wykorzystanie żywieniowe i przemysłowe. Nauka Przyr Technol 2014;8(3):1-12.

5. Gibiński M, Gumul D, Korus J. Prozdrowotne właściwości owsa i produktów owsianych. Żywn Nauka Technol Jakość 2005;4(45):49-60. 
6. Peckenpaugh N. Podstawy żywienia i dietoterapia. Wrocław: Urban \& Partner; 2015

7. Cho N, Kirigia J, Mbanya J, Ogurstova K, Guariguata L, Rathmann W. IDF diabetes atlas. 8th ed. Brussels: International Diabetes Federation; 2017.

8. Jarosz M, Kłosiewicz-Latoszek L. Cukrzyca. Zapobieganie i leczenie. Porady lekarzy i dietetyków. Warszawa: Wydawnictwo Lekarskie PZWL; 2007.

9. Zalecenia kliniczne dotyczące postępowania u chorych na cukrzycę 2017. Stanowisko Polskiego Towarzystwa Diabetologicznego. Diabetol Prakt 2017;6(A1):A1-A180.

10. Bienkiewicz M, Bator E, Bronikowska M. Błonnik pokarmowy i jego znaczenie w profilaktyce zdrowotnej. Probl Hig Epidemiol 2015;96(1):57-63.

11. InterAct Consortium. Dietary fibre and incidence of type 2 diabetes in eight European countries: the EPIC-InterAct Study and a meta-analysis of prospective studies. Diabetologia 2015;58(7):1394-408. doi: 10.1007/ s00125-015-3585-9.

12. Anderson JW, Radles KM, Kendall CW, Jenkins DJ. Carbohydrate and fiber recommendations for individuals with diabetes: a quantitative assessment and meta-analysis of the evidence. J Am Coll Nutr 2004;23(1):5-17.

13. Gajewska D, Myszkowska-Ryciak J, editors. Wybrane problemy dietoprofilaktyki i dietoterapii chorób przewlekłych. Warszawa: Publikacje - Polskie Towarzystwo Dietetyki; 2016.

14. Murray RK, Granner DK, Rodwell VW. Biochemia Harpera ilustrowana. 6th ed. Warszawa: Wydawnictwo Lekarskie PZWL; 2008.
15. Kapłon-Cieślicka A, Filipiak KJ. Leczenie hipercholesterolemii w warunkach ambulatoryjnych w Polsce. Chor Serca Naczyń 2015;12(4):240-8.

16. Gibiński M. $\beta$-glukany owsa jako składnik żywności funkcjonalnej. Żywn Nauka Technol Jakość 2008;2(57):15-29.

17. Przybylska D, Kurowska M, Przybylski P. Otyłość i nadwaga w populacji rozwojowej. Hygeia Public Health 2012;47(1):28-35.

18. Szymocha M, Bryła M, Maniecka-Bryła I. Epidemia otyłości w XXI wieku. Zdr Publ 2009;119(2):207-12.

19. Wąsowski M, Walicka M, Marcinowska-Suchowierska E. Otyłość - definicja, epidemiologia, patogeneza. Post Nauk Med 2013;26(4):301-6.

20. Ciborowska H, Rudnicka A. Dietetyka. Żywienie zdrowego i chorego człowieka. 4th ed. Warszawa: Wydawnictwo Lekarskie PZWL; 2014.

21. Zdrojewicz Z, Lubańska A, Wyderkowska A. Wpływ spoży wania płatków owsianych na organizm człowieka. Med Rodz 2017;20(2):118-23.

22. Rebello CJ, Chu YF, Johnson WD, Martin CK, Han H, Bordenave N, et al. The role of meal viscosity and oat $\beta$-glucan characteristics in human appetite control: a randomized crossover trial. Nutr J 2014;13:49.

23. Hong-Chou C, Chien-Ning H, Da-Ming Y, Shing-Jung W, Chiung-Huei P, Chau-Jong W. Oat prevents obesity and abdominal fat distribution, and improves liver functions in humans. Plant Foods Hum Nutr 2013;68:18-23. 